Pamiętnik Literacki 2013, 2, s. 199-203
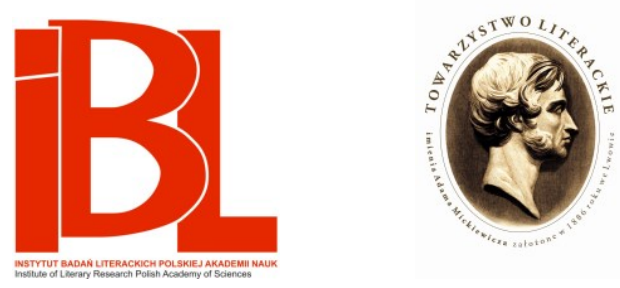

Jeszcze raz o Prusie i Żeromskim : czego nie wydrukował Pigoń

Zdzisław Jerzy Adamczyk 
Pamiętnik Literacki CIV, 2013, z. 2

PL ISSN 0031-0514

ZDZISŁAW JERZY ADAMCZYK

(Akademia Humanistyczna im. Aleksandra Gieysztora w Pułtusku)

\section{JESZCZE RAZ O PRUSIE I ŻEROMSKIM: CZEGO NIE WYDRUKOWAŁ PIGOŃ}

Znajomość Prusa i Żeromskiego oraz wzajemne między nimi relacje były przedmiotem zainteresowania wielu badaczy i tematem licznych prac ${ }^{1}$; opublikowane zostały odnoszące się do tych relacji listy, wspomnienia i inne dokumenty - a mimo to sporo tutaj jeszcze kwestii niewyjaśnionych czy może nawet zagadkowych. Niejasności otaczają dotąd np. drobny, ale ważny epizod we wzajemnych stosunkach obu twórców, kiedy to - wiosną 1897 - Żeromski kopiował dla Prusa jakieś, jak to określał, ,stare brednie”, za co Prus wynagrodził go kwotą 5 rubli. Ponieważ listy Żeromskiego do Prusa nie zachowały się, wiadomo na ten temat właściwie tylko tyle, ile napisał sam Żeromski w listach do żony, a także Prus w listach i liścikach do Żeromskiego, z których pewna część - nie wiedzieć dlaczego - nie została dotąd opublikowana.

Listy Żeromskiego do żony z r. 1897 ogłosił (jeszcze w r. 1935) Wacław Borowy. W listach tych Żeromski narzeka na Prusa; w dniu 4 VI skarży się: „Trzy dni już przepisuję w Bibliotece Zamoyskich stare brednie dla Prusa. Jest tego formalna kupa. Jużem napisał jakieś 18 kartek i jeszcze będzie ze dwa dni pisania po cztery godziny”; w poniedziałek 7 VI informuje: „W sobotę widziałem się z Prusem. Ma być dzisiaj u mnie w sprawie tych kopii jego nowel"; około 19 VI donosi żonie, że Prus „wpakował” mu 5 rubli ,za przepisywanie”2. Wiadomo zatem, iż Żerom-

1 Zob. S. P i oł u n - N o y s z e w s k i, Stefan Żeromski. Dom, dzieciństwo i młodość. Warszawa 1928, s. 175-179, 186-187, 327-334. - Z. J. A d a m c z y k, Jak to było z Prusem i Żeromskim. „Słowo Ludu. Magazyn Niedzielny” (Kielce) 1964, nr 219. - K. J a błoń s k a, Czy tylko mity i legendy. Jw., nr 224. - H. M ark i e w i c z, Żeromski i Prus. Gawęda historycznoliteracka. W: W kregu Żeromskiego. Rozprawy i szkice historycznoliterackie. Warszawa 1977. - Z. J. A d a m c z y k, Cherchez la femme? Bolestaw Prus w listach (czyli w życiu) Stefana Żeromskiego. W zb.: Prus i inni. Prace ofiarowane Profesorowi Stanisławowi Ficie. Red. J. A. Malik, E. Paczoska. Lublin 2003. - S. K a r p o w i c z-S ł o w i k o w s k a, Czy byt epistolarny dwugłos? Fakty i mity o korespondencji Żeromskiego i Prusa. W zb.: Światy Stefana Żeromskiego. Studia. Red. M. J. Olszewska, G. P. Bąbiak. Warszawa 2005; tam również najdokładniej omówiona literatura przedmiotu. Ostatnia praca na ten temat to wygłoszony w czerwcu 2011 w Białymstoku na konferencji Stefan Żeromski i tradycje inteligencji polskiej. Idee - estetyka - język referat S. K a r pow i c z-S łow i kow ski e j „Szorstka przyjaźn’”. Żeromski w oczach Prusa.

2 W. B o r o w y, Listy Stefana Żeromskiego z lat 1896-1897. „Ruch Literacki” 1935, nr 7/8, s. $195-198$. 
ski przepisywał jakieś nowele Prusa; nie wiadomo, jakie nowele - i dlaczego to robił.

Listy Prusa do Żeromskiego i jego żony ujrzały światło dzienne w ćwierć wieku później. W roku 1959, w opracowaniu Krystyny Tokarzówny, wydany został tom zbierający wszystkie zachowane listy autora Lalki, m.in. 35 listów Prusa do Oktawii Żeromskiej i jeden list adresowany do obojga małżonków Żeromskich; w tych 36 listach o owym kopiowaniu tekstów Prusa nie wspomina się, prawie wszystkie bowiem pochodzą sprzed roku $1897^{3}$. W dwa lata po ukazaniu się książkowej edycji Listów, jako jej uzupełnienie, Pięć listów Bolestawa Prusa do Stefana i Oktawii Żeromskich opublikował w „Ruchu Literackim” Stanisław Pigoń4, który w tym czasie zajmował się korespondencją Żeromskiego i z tej racji miał dostęp do wielkiego archiwum znajdującego się w Konstancinie w posiadaniu Anny i Moniki Żeromskich ${ }^{5}$. Pigoń miał wówczas w rękach cały zespół listów i liścików Prusa do Żeromskich, zdecydował się jednak ogłosić z niego tylko 5 listów - 3 do autora Promienia i 2 do jego żony; teksty te - powiedzmy od razu - nie odsłaniają jakichś ważnych, a wcześniej nie znanych zdarzeń ani z życia Prusa, ani z biografii Żeromskiego i jego żony. W jednym z liścików do Oktawii (z r. 1897) Prus prosił o wynajęcie dla niego w Nałęczowie pokoju na lato i o wysłanie koni na stację kolejową, w drugim (z r. 1904) donosił o śmierci długoletniej służącej. Do Żeromskiego w r. 1892 pisał, iż wysyła mu list polecający do profesora Bolesława Ulanowskiego w Krakowie, w ostatnim dniu grudnia 1903 gratulował mu (na kartce pocztowej) powrotu do zdrowia i ukończenia Popiołów, a w liściku z 16 III 1897, dość tajemniczo informował, iż „musi jeszcze zatrzymać się parę dni, tym więcej, że może w redakcji »Kuriera Warszawskiego« znajdzie to, czego mu potrzeba”. Objaśniając ten list Pigoń zanotował: „Żeromski odpisywał podówczas dla Prusa w Bibliotece Zamoyskich materiały archiwalne".

Nie opublikował natomiast Pigoń kilku innych drobiazgów ze wspominanego zespołu, który dziś stanowi własność Biblioteki Narodowej ${ }^{6}$. Zespół ten oprócz 5 listów wydrukowanych w „Ruchu Literackim” zawiera:

- maszynopis artykułu Prusa $Z$ powodu siedleckich wypadków, pod koniec 1906 r. ofiarowanego do redagowanej i wydawanej przez Żeromskiego książki $\mathrm{Na}$ nowa szkołę, z której dochód miał być przeznaczony na budowę ochronki w Nałęczowie; artykuł ten - z licznymi i rozległymi ręcznymi poprawkami-pierwotnie miał być kroniką tygodniową, ostatecznie jednak wśród kronik Prusa nie znalazł się i światło dzienne ujrzał dopiero w książce Na nowa szkołę;

- bilet wizytowy Aleksandra Głowackiego (czysty, bez tekstu);

- bilet wizytowy z konwencjonalnymi życzeniami imieninowymi dla Żeromskiego: „Z p. i. 2 IX 1905”7;

3 A. Głow a ck i (B. Pru s), Listy. Oprac., komentarz, posł. K. To k a r zó w n a. Warszawa 1959.

4 S. P i g o ń, Pięć listów Bolestawa Prusa do Stefana i Oktawii Żeromskich. „Ruch Literacki” 1961, $\mathrm{nr} 4 / 5$.

5 Zob. Z. J. A d a m c z y k, Stanisława Pigonia praca nad listami Stefana Żeromskiego. W zb.: Profesor z Komborni. Stanisław Pigoń w czterdziestą rocznicęśmierci. Red. K. Fiołek. Kraków 2010.

6 Bibl. Narodowa, rkps akc. 17 218, t. 11.

7 Kremowy kartonik 5,2 × 9,3 cm z nadrukiem: „Aleksander Głowacki”; tekst atramentem czarnym. 
- bilet wizytowy, niedatowany, z pozdrowieniami: „Szanownym i Kochanym Panom: Witkiewiczowi i Żeromskiemu pozdrowienia zasyłam"s; wymieniony tutaj (na pierwszym miejscu) pan Witkiewicz to zapewne Jan Witkiewicz (18811958), architekt i działacz społeczny, od r. 1905 związany z Nałęczowem, a wkrótce potem i z rodziną Żeromskich, bo od r. 1908 mąż Henryki Rodkiewiczówny, córki Oktawii Żeromskiej z pierwszego małżeństwa. W roku 1905 opracował projekt i nadzorował budowę ,chaty” Żeromskiego w Nałęczowie, a później nałęczowskiej ochronki; w r. 1906 pomagał Żeromskim przy wydawaniu książki Na nowa szkołe, przypuszczalnie więc bilecik z pozdrowieniami dla Witkiewicza i Żeromskiego związany był z tą publikacją, a może towarzyszył przekazywanemu maszynopisowi artykułu $Z$ powodu siedleckich wypadków?

Ponadto znajdują się tutaj dwa autografy wyjaśniające, jakie to „materiały archiwalne" Żeromski przepisywał dla Prusa. Pierwszy to kartka białego papieru o wymiarach 10,7 × 14,4 cm, na której znajduje się wykonana czarnym atramentem, ręką Prusa, następująca notatka:

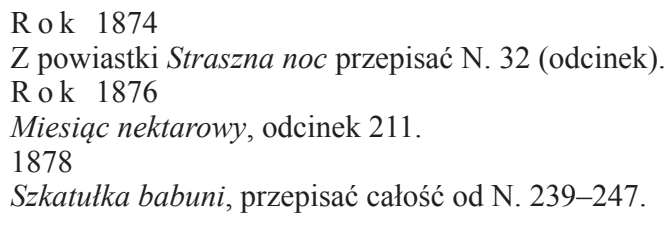

Drugi autograf to bilet wizytowy, na którym ołówkiem słowa skreślone ręką Prusa: „Złoty Panie! Straszna noc drukowana nie w 1874, lecz w 1879. Zostaję z szacunkiem G1." 9

Z ostatnich dwóch dokumentów wynika, iż Żeromski kopiował dla Prusa nie „materiały archiwalne”, ale fragmenty jego opowiadań zamieszczanych przed laty w „Kurierze Warszawskim”; nietrudno zorientować się, że zajęcie to związane było z przygotowywaną na jubileusz 25-lecia pracy pisarskiej Prusa 4-tomową edycją jego Pism, w której miały się znaleźć utwory nowelistyczne i powieściowe wcześniej publikowane w edycjach książkowych bądź drukowane w czasopismach ${ }^{10}$. Autor musiał wtedy dostarczyć wydawcy albo rękopisy, albo wycinki (z pism lub książek) z tekstem swych utworów; wiosną 1897 była to sprawa pilna, a w czerwcu arcypilna ${ }^{11}$. Prus nie posiadał kompletu wycinków; w połowie marca, jak świadczy jego liścik do Żeromskiego z 16 III 1897, spodziewał się, że archiwalne numery „Kuriera Warszawskiego" znajdzie w redakcji, ale gdy i w czerwcu nie miał w ręku wszystkich potrzebnych tekstów, o pomoc zwrócił się do Żeromskiego, który miał już obiecaną pracę w Bibliotece Ordynacji Zamojskiej (formalnie został zaangażo-

${ }^{8}$ Kremowy kartonik 5,7 × 9,6 cm z nadrukiem: „Aleksander Głowacki”; tekst atramentem czarnym.

9 Kremowy kartonik 4,9 × 11,6 cm z nadrukiem: „Aleksander Głowacki”. Liścik niedatowany.

${ }^{10}$ B. Pru s (A. Głow a c k i), Pisma. Wydanie jubileuszowe. T. 1-4. Warszawa 1897.

${ }_{11}$ Rosyjska cenzura w Warszawie wydała zezwolenia na druk (,dozwoleno cenzuroju”) - oddzielne dla każdego z czterech tomów - w lipcu 1897. Najwcześniejsza data zezwolenia jest na tomie pierwszym: 8 VII (st. st.), najpóźniejsza na tomie drugim: 29 VII st. st., co odpowiada dacie 10 VIII w naszym kalendarzu; w tym właśnie tomie, zapewne najpóźniej złożonym w urzędzie cenzury, znajdują się m.in. przepisywane przez Żeromskiego opowiadania Prusa Szkatułka babuni oraz Straszna noc. 
wany dopiero 27 X 1897), często w Bibliotece przebywał, miał więc do dawnych numerów „Kuriera” łatwy dostęp.

Na życzenie Prusa Żeromski przepisał wówczas: całe opowiadanie Szkatułka babuni (8 odcinków), wydrukowane w „Kurierze Warszawskim” w r. 1878, w numerach 239-245 i 247 (od 24 X do 4 XI - z jedną przerwą), pierwszy (z ośmiu) odcinek opowiadania Miesiac nektarowy, który ukazał się w numerze 211 „Kuriera Warszawskiego" z 26 IX 1876, jeden odcinek opowiadania Straszna noc, drukowanego w „Kurierze” w r. 1879 w numerach 47-52 (od 27 II do 6 III); nie wiadomo, który to był odcinek, gdyż notatka Prusa odsyłająca do numeru 32 jest błędna (w tej sprawie kopista uzyskał pewnie od autora jakieś wyjaśnienie ustne). Takie to były owe przepisywane przez Żeromskiego „materiały archiwalne”.

Ta informacja wymaga komentarza.

Prośbę Prusa o przepisanie (i to pilne!) kilkudziesięciu stronic tekstu Żeromski mógł traktować jako prośbę o przysługę, którą należy wyświadczyć wybitnemu twórcy, znajomemu z Nałęczowa i z kontaktów towarzyskich w innych miejscach i czasach, przyjacielowi żony itd. - taki domysł zdaje się uprawniać zarówno wiedza o jego wcześniejszej znajomości z Prusem, jak i ten fragment listu Żeromskiego do żony, gdzie donosi on, iż Prus ,wpakował" mu za przepisywanie 5 rubli. Określenie to można chyba rozumieć w ten sposób, iż autor Syzyfowych prac pieniędzy tych nie chciał przyjmować.

Prus - wypada zauważyć - ciągle traktował Żeromskiego z wysoka i protekcjonalnie; cała ta historia z przepisywaniem i zapłatą nie pozostawia w tej kwestii wątpliwości. A przecież wiosną 1897 Żeromski miał już w literaturze polskiej niezłą pozycję. Był autorem wydanych wcześniej i przyjętych przez krytykę z wielkim zainteresowaniem dwóch tomów opowiadań; od 24 IV 1897 jego powieść Promień drukował w odcinku warszawski „Głos”, inna zaś powieść, Syzyfowe prace, czekała na publikację w krakowskiej „Nowej Reformie” (druk rozpoczął się 7 VII 1897); w kręgach młodej literatury był już twórcą znanym, podziwianym; jego nowele zamieszczane w r. 1896 i 1897 w pismach warszawskich przedrukowywane były przez gazety poznańskie i galicyjskie, a także rozpoczynały (od przekładów w Rosji) karierę międzynarodową. Literackich sukcesów męża pani Oktawii Prus nie doceniał, protekcjonalny zaś stosunek autora Lalki do Żeromskiego był dlań z pewnością trudny do przełknięcia. A całą historię przepisywania i otrzymaną od Prusa zapłatę mógł on potraktować jako upokorzenie.

I jeszcze słówko na temat decyzji Pigonia, który, wydając 5 listów Prusa do Żeromskich, nie poinformował, iż jest to tylko wybór z większego zespołu. W żaden sposób nie sugerował, rzecz jasna, że prezentuje wszystkie zachowane liściki Prusa do Żeromskich, ale też nigdzie nie zdradził, iż pozostawia kilka nieopublikowanych.

Trudno odgadnąć, dlaczego Pigoń nie ogłosił drukiem całego znajdującego się w r. 1961 w jego rękach zespołu. Czy zabrakło mu czasu, by wyśledzić, o co mogło chodzić w karteczce z rejestrem utworów do przepisania, wobec czego ograniczył się do przedstawienia listów łatwych w opracowaniu, bo przez nadawcę datowanych, a także nie wymagających gruntowniejszych objaśnień? Czy np. uznał, że bilety wizytowe i notatki nie są warte uwagi i nie stanowią dla historyka literatury takiego interesu jak listy obszerniejsze?

Pigoń nie miał, oczywiście, obowiązku publikowania całego zespołu, mógł 
dokonać wyboru, wydrukować tylko część listów. Czy jednak nie powinien był poinformować o tym wyraźnie? Czy nie taki jest obowiązek wydawcy?

W roku 1969, w 8 lat po ogłoszeniu przez Pigonia Pięciu listów, wydany został kalendarz życia i twórczości Prusa; jego autorzy, wykorzystując zarówno publikację Pigonia, jak i listy Żeromskiego z 1897 r. wydrukowane przez Borowego, odnotowali (nawet w dwóch miejscach) także fakt kopiowania przez Żeromskiego dla Prusa ,jakichś tekstów”. Informacja została podana tak:

W celu umożliwienia zarobku Stefanowi Żeromskiemu, nie posiadającemu wówczas stałego płatnego zajęcia, Prus powierza mu przepisywanie jakichś tekstów w Bibliotece Zamoyskich $^{12}$.

Tutaj komentarz nie jest chyba potrzebny.

\section{Abstract}

ZDZISŁAW JERZY ADAMCZYK

(Pultusk Academy of Humanities)

\section{ON PRUS AND ŻEROMSKI ONCE AGAIN. WHAT PIGOŃ DID NOT PUBLISH}

The article refers to an episode in the story of Bolesław Prus and Stefan Żeromski's acquaintance. From Prus' letters written in 1897 published here it follows what work Żeromski did for him.

12 Bolestaw Prus 1847-1912. Kalendarz życia i twórczości. Oprac. K. To k a rzó w na, S. Fit a. Red. Z. Szweykowski. Warszawa 1969, s. 496, 501. 